\title{
Respon Tanaman Cabai Besar (Capsicum annuum L.) terhadap Pengayaan Trichoderma pada Media Tanam dan Aplikasi Pupuk Boron
}

\author{
Response of (Capsicum annuum L.) to Trichoderma Enrichment in Planting Medium \\ and Application of Boron Fertilizer
}

\author{
Rahmansyah Dermawan ${ }^{1 *}$, Muh. Farid B. D. R. ${ }^{1}$, Ifayanti Ridwan Saleh ${ }^{1}$, dan Reni Syarifuddin ${ }^{1}$
}

Diterima 06 November 2018/Disetujui 04 Februari 2019

\begin{abstract}
A study was conducted to determine the response of several varieties of large chilli (Capsicum annuum L.) to Trichoderma enrichment on planting media and Boron fertilizer applications. The study was conducted from June to September 2017 at the Experimental Garden of the Faculty of Agriculture, Hasanuddin University, Makassar in the form of factorial Split Plot Design with 2 factors. Experiments were set with large chili varieties as the main plot consisting of var. Karina, var. Tombak, and var. Panex $100 \mathrm{Fl}$, while the combination of Trichoderma enrichment and Boron fertilizer was set as subplots consist of 6 treatment combinations. The results show that there was a significant interaction between the treatment of varieties and Trichoderma-Boron on plant height parameter and there was a significant effect of the varieties treatment on the number of productive branches and the number of fruits per plant. In addition, significant effect of the Trichoderma-Boron treatment was shown in the parameters of fruit length per plant 100 HST. The interaction that gave the best results was in the treatment of Trichoderma asperellum $4 \mathrm{~g} \mathrm{plant}^{-1}$ and Panex $100 \mathrm{Fl}$ varieties on plant height of $47.77 \mathrm{~cm}$. The treatment of varieties that gave the best results was Karina variety and the combination treatment of Trichoderma-Boron that gave the best results was the treatment of Trichoderma asperellum $4 \mathrm{~g}_{\text {plant }}{ }^{-1}+$ Boron $1 \mathrm{mg} \mathrm{L}^{-1}$.
\end{abstract}

Keywords: Capsicum annuum L., microbe, boron fertilizer, varieties

\begin{abstract}
ABSTRAK
Penelitian dilaksanakan untuk mengetahui respon beberapa varietas cabai besar (Capsicum annuиm L.) terhadap pengayaan Trichoderma pada media tanam dan aplikasi pupuk Boron. Penelitian berlangsung dari bulan Juni-September 2017 di Kebun Percobaan Fakultas Pertanian Universitas Hasanuddin, Makassar dan dilaksanakan dalam bentuk percobaan Rancangan Petak Terpisah dalam rancangan acak kelompok faktorial dengan 2 faktor. Percobaan diatur dengan varietas cabai besar sebagai petak utama yaitu varietas Karina (V1), varietas Tombak (V2), dan varietas Panex 100 F1(V3) sedangkan kombinasi cendawan Trichoderma dan pemupukan Boron sebagai anak petak terdiri atas 6 kombinasi perlakuan. Penelitian menunjukkan interaksi yang nyata antara perlakuan varietas dan Trichoderma-Boron pada parameter tinggi tanaman dan terdapat pengaruh nyata dari perlakuan varietas terhadap jumlah cabang produktif dan jumlah buah per tanaman. Pengaruh nyata dari perlakuan Trichoderma-Boron ditunjukkan pada parameter panjang buah per tanaman umur 100 HST. Interaksi yang memberikan hasil terbaik yaitu pada perlakuan Trichoderma asperellum $4 \mathrm{~g} \mathrm{tan}^{-1} \mathrm{dan}$ varietas Panex $100 \mathrm{~F} 1$ pada tinggi tanaman yaitu $47.77 \mathrm{~cm}$. Perlakuan varietas memberikan hasil terbaik pada varietas Karina dan perlakuan kombinasi Trichoderma-Boron memberikan hasil terbaik pada perlakuan Trichoderma asperellum $4 \mathrm{~g} \mathrm{tan}^{-1}+$ Boron $1 \mathrm{mg} \mathrm{L}^{-1}$.
\end{abstract}

Kata kunci: Capsicum annuиm L., mikroba, pupuk boron, varietas

${ }^{1}$ Departemen Budidaya Pertanian, Fakultas Pertanian, Universitas Hasanuddin, Makassar E-mail : radesya09@gmail.com (*Penulis korespondensi) 


\section{PENDAHULUAN}

Cabai besar (Capsicum annuum L.) termasuk komoditas sayuran penting di Indonesia yang banyak dimanfaatkan sebagai penyedap masakan. Selain zat gizi protein, lemak, dan karbohidrat, cabai besar juga mengandung vitamin $\mathrm{A}, \mathrm{B} 1$ dan vitamin $\mathrm{C}$ yang merupakan zat-zat yang diperlukan untuk kesehatan manusia (Prayudi, 2010). Berdasarkan data Kementerian Pertanian (2009), luas panen cabai pada tahun 2016 adalah sebesar 123.404 ha dengan produksi 1.05 juta ton dan produktivitas sebesar 8.47 ton $\mathrm{ha}^{-1}$. Nilai produksi meningkat pada tahun 2017 yang mencapai 1.2 juta ton atau mengalami pertumbuhan sebesar $15.37 \%$ dari tahun sebelumnya. Meskipun demikian, produktivitas ini masih jauh dari potensi produktivitas cabai yang dapat mencapai 20 ton ha ${ }^{-1}$ (Syukur et al., 2007).

Produksi cabai besar dalam negeri yang masih tergolong rendah diasumsikan disebabkan oleh penggunaan benih varietas lokal atau benih tanaman cabai yang diperoleh dari musim tanam sebelumnya dan dilakukan secara turun temurun (Sumarni dan Muharam, 2003). Cabai varietas Panex 100 F1 merupakan salah satu jenis cabai besar hibrida yang dapat dibudidayakan pada dataran menengah dan dataran tinggi. Cabai varietas ini toleran terhadap suhu yang tinggi, dan memiliki tipe tajuk tanaman melebar. Selain itu terdapat beberapa varietas unggul lainnya yaitu varietas Tombak. Varietas jenis ini memiliki penampilan tanaman tegap serta kuat pertumbuhannya dengan rentang daerah adaptasi mulai dataran rendah sampai tinggi. Varietas Tombak memiliki buah besar, lebat, berwarna merah, dan kulitnya halus. Varietas lain yang juga merupakan benih unggul adalah cabai hibrida F1 Karina. Cabai jenis ini memiliki pertumbuhan tanaman kuat, seragam dan kokoh dengan adaptasi yang baik.

Kendala lain yang kerap dihadapi oleh petani dalam budidaya cabai adalah tingkat gugur bunga dan buah yang cukup tinggi. Berdasarkan laporan penelitian, hanya $52.6 \%$ keberhasilan bunga menjadi buah dimana dari 500 bunga yang terbentuk hanya 263 bunga yang menjadi buah (Alqamari, 2016). Asupan nutrisi seimbang melalui pemupukan diharapkan mampu menghasilkan produksi yang tinggi. Menurut Sutedjo (2010), produksi maksimal dapat dicapai melalui pemupukan yang merupakan bagian penting dalam pemeliharaan tanaman (Sutedjo, 2010). Unsur hara yang ditambahkan melalui pupuk dapat berupa unsur hara makro dan mikro yang dibutuhkan untuk pertumbuhan dan produksi tanaman. Unsur hara mikro seperti Boron juga merupakan unsur hara penting bagi tanaman. Boron dibutuhkan tanaman dalam proses metabolisme dan pengangkutan gula, perkembangan meristematik jaringan, perpanjangan akar, pembentukan serbuk sari dan penyerbukan. Penambahan unsur mikro seperti Boron dengan dosis yang tepat akan berpengaruh baik bagi tanaman. Tidak semua kandungan Boron di dalam tanah dapat tersedia bagi tanaman. Hanya sekitar 0.5-2.5\% kandungan Boron dalam tanah dari 0.5-2.0 ppm yang dapat dimanfaatkan oleh tanaman (Kumar et al., 2016).

Permasalahan lain yang kerap dialami oleh petani adalah kondisi lahan budidaya yang kurang optimal karena rendahnya kesuburan tanah. Jika tidak diatasi dengan baik, hal ini dapat menurunkan produksi cabai. Untuk meningkatkan kesuburan tanah salah satunya dengan pengayaan media tanam dengan menggunakan mikroba. Salah satu mikroba yang banyak dimanfaatkan adalah Trichoderma yang mampu bersimbiosis mutualisme dengan akar dan tidak berbahaya bagi tanaman (Subhan et al., 2012). Cendawan ini membantu tanaman induk menyerap unsur hara tertentu seperti fosfor (P) (Poulton et al., 2011). Pengayaan Trichoderma pada lahan diharapkan mampu meningkatkan kesuburan tanah sekaligus meningkatkan ketersediaan hara bagi pertumbuhan dan perkembangan tanaman. Tujuan yang ingin dicapai pada penelitian ini adalah mendapatkan informasi mengenai respon tanaman cabai besar terhadap pemupukan Boron dan pemberian Trichoderma pada media tanam. Diharapkan informasi yang diperoleh dapat membantu petani cabai khususnya dalam mengatasi gugur bunga dan buah pada cabai. Dengan demikian, produksi dan produktivitas cabai dapat ditingkatkan.

\section{BAHAN DAN METODE}

Penelitian dilakukan di Kebun Percobaan Fakultas Pertanian Universitas Hasanuddin, Makassar. Penelitian berlangsung 
dari Juni sampai September 2017 dalam bentuk percobaan berdasarkan rancangan petak terpisah. Petak utama disusun berdasarkan rancangan acak kelompok dengan 3 taraf dan diulang sebanyak 3 kali. Petak utama adalah varietas cabai besar yang terdiri atas 3 taraf yaitu varietas Karina (V1), varietas Tombak (V2), dan varietas Panex 100 F1(V3). Anak petak adalah kombinasi pengayaan Trichoderma dan pemupukan mikro Boron yang terdiri atas 6 kombinasi perlakuan, yaitu: Tanpa Trichoderma + tanpa Boron (T0), Trichoderma harzianum $4 \mathrm{~g} \tan ^{-1}$ (T1), Trichoderma asperellum $4 \mathrm{~g} \tan ^{-1}$ (T2), Trichoderma harzianum $4 \mathrm{~g} \mathrm{tan}^{-1}+$ Boron $1 \mathrm{mg}$ $\mathrm{L}^{-1}$ (T3), Trichoderma asperellum $4 \mathrm{~g} \mathrm{tan}^{-1}+$ Boron $1 \mathrm{mg} \mathrm{L}^{-1}$ (T4), Boron $1 \mathrm{mg} \mathrm{L}^{-1}$ (T5). Setiap kombinasi perlakuan petak utama dan anak petak terdiri dari 3 tanaman sehingga terdapat 162 satuan percobaan. Penggunaan dosis Boron berdasarkan (Marschner, 2012) dan dosis Trichoderma berdasarkan (Rosmana et al., 2016)

Bahan dan alat yang digunakan pada penelitian ini yaitu benih cabai besar varietas Karina produksi PT. Hextar Seed Indonesia, varietas Tombak produksi PT. Bisi Internasional Tbk, varietas Panex 100 F1 produksi PT. East West Seed Indonesia, Trichoderma harzianum, Trichoderma asperellum, pupuk mikro Boron, air, Atonik, tanah, pupuk kandang, pestisida, cangkul, sekop, timbangan, kamera, mistar, polibag ukuran $40 \mathrm{~cm}$ x $50 \mathrm{~cm}$, papan sampel, papan perlakuan, alat tulis menulis.

Pemberian Trichoderma dilakukan dengan jalan ditaburkan pada tiap lubang tanam bertepatan dengan saat pindah tanam. Pemupukan Boron diaplikasikan sebanyak 3 kali, pada masa vegetatif (20 HST), masa pembungaan (40 HST) dan terbentuk pentil buah (50 HST). Pemupukan Boron dilakukan dengan cara disemprotkan pada bagian daun, bunga, dan buah. Pemupukan diaplikasikan pada pukul 07.00 - 08.00. Pemupukan susulan dilakukan 3 kali yaitu 7 HST, 30 HST, dan 50 HST. Pupuk yang digunakan adalah pupuk urea $0.87 \mathrm{~g} \mathrm{tan}^{-1}$, SP36 $1.75 \mathrm{~g} \mathrm{tan}^{-1}$, dan KCl $1.49 \mathrm{~g}$ $\tan ^{-1}$. Dosis pemupukan diberikan berdasarkan uji laboratorium analisis tanah dan volume tanah yang digunakan dalam polibag. Pemanenan dilakukan berdasarkan kriteria panen yaitu cabai yang sudah berwarna merah (100\%). Pemanenan dilakukan sebanyak 3 kali yaitu pada 90 hari setelah tanam (HST), 100 HST dan 110 HST.

Peubah pengamatan yang digunakan pada penelitian ini yaitu tinggi tanaman, jumlah cabang produktif, jumlah buah gugur per tanaman, jumlah buah per tanaman, dan panjang buah per tanaman.

\section{HASIL DAN PEMBAHASAN}

\section{Tinggi Tanaman}

Data tinggi tanaman cabai besar dan sidik ragamnya pada umur 20 HST (Hari Setelah Tanam) menunjukkan bahwa perlakuan varietas cabai besar dan perlakuan kombinasi Trichoderma-Boron berpengaruh tidak nyata sedangkan interaksinya berpengaruh nyata. Rata-rata tinggi tanaman berbagai varietas cabai besar pada perlakuan kombinasi Trichoderma-Boron 20 HST dapat dilihat pada Tabel 1.

Berdasarkan uji BNT pada taraf $\alpha=0.05$ yang ditunjukkan dalam Tabel 1, perlakuan Trichoderma asperellum $4 \mathrm{~g} \mathrm{tan}^{-1}$ pada varietas Panex 100 F1 (T2V3) menghasilkan tinggi tanaman yang tertinggi yaitu $47.77 \mathrm{~cm}$ dan berbeda nyata pada perlakuan Trichoderma harzianum $4 \mathrm{~g} \mathrm{tan}{ }^{-1}$ dan varietas Tombak (T3V2) yang memiliki tinggi tanaman terendah yaitu $39.22 \mathrm{~cm}$.

Hal ini menunjukkan bahwa jenis varietas yang digunakan berpengaruh terhadap tinggi tanaman.Varietas Panex 100 F1 menunjukkan tinggi tanaman tertinggi dibandingkan dengan varietas lainnya. Perbedaan ini menunjukkan respon yang berbeda dari varietas terhadap lingkungan tumbuh yang dapat dikaitkan dari susunan genotipe yang dimiliki setiap varietas. Susunan genotipe akan menentukan karakteristik potensi genetik mulai dari ciri morfologi hingga mekanisme yang mengatur metabolisme yang pada akhirnya akan mempengaruhi kemampuan produksi suatu varietas. Dengan demikian, penggunaan varietas unggul merupakan salah satu komponen penting dalam peningkatan produksi cabai selian dari praktekpraktek pemupukan (Hayati, 2012). 
Tabel 1. Tinggi tanaman berbagai varietas cabai besar pada kombinasi perlakuan Trichoderma-Boron pada 20 HST

\begin{tabular}{|c|c|c|c|c|c|}
\hline \multirow[b]{2}{*}{ Kombinasi Trichoderma-Boron } & \multicolumn{3}{|c|}{ Varietas } & \multirow{2}{*}{$\begin{array}{l}\text { Rata- } \\
\text { rata } \\
(\mathrm{cm})\end{array}$} & \multirow{2}{*}{$\begin{array}{c}\text { NP BNT } \\
0.05\end{array}$} \\
\hline & Karina & Tombak & $\begin{array}{l}\text { Panex } \\
\text { 100F1 }\end{array}$ & & \\
\hline & \multicolumn{3}{|c|}{ 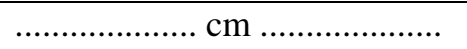 } & & \\
\hline Tanpa Trichoderma + tanpa Boron & $42.16^{c} \mathrm{p}$ & $43.66^{b}{ }_{p}$ & $46.16^{b}$ & 43.99 & \\
\hline T. harzianum $4 \mathrm{~g} \mathrm{tan}^{-1}$ & $40.54{ }_{p}^{d}$ & $44.49^{a}{ }_{p}$ & $43.64{ }_{p}^{d}$ & 42.89 & \\
\hline T. asperellum $4 \mathrm{~g} \mathrm{tan}^{-1}$ & $39.26{ }_{\mathrm{q}}^{\mathrm{e}}$ & $41.31_{\mathrm{q}}^{\mathrm{c}}$ & $47.77^{a}$ & 42.78 & 4.79 \\
\hline T. harzianum $4 \mathrm{~g} \mathrm{tan}^{-1}+$ Boron $1 \mathrm{~m} \mathrm{~L}^{-1}$ & $41.69^{c}{ }_{p}^{1}$ & $39.22 \mathrm{~d}_{\mathrm{q}}$ & $44.58{ }^{c}$ & 41.83 & \\
\hline T. asperellum $4 \mathrm{~g} \mathrm{tan}^{-1}+$ Boron $1 \mathrm{mg} \mathrm{L}^{-1}$ & $44.24{ }_{\mathrm{p}}^{\mathrm{b}}$ & $43.62 \mathrm{~b}_{\mathrm{p}}$ & $46.33 \mathrm{~b}_{\mathrm{p}}$ & 44.73 & \\
\hline Boron $1 \mathrm{mg} \mathrm{L}^{-1}$ & $46.23{ }^{a}{ }_{p}^{a}$ & $43.14^{b}{ }_{p}$ & $40.97 \mathrm{e}_{\mathrm{q}}$ & 43.45 & \\
\hline Rata-rata & 42.35 & 42.57 & 44.91 & & \\
\hline NP BNT 0.05 & & 0.78 & & & \\
\hline
\end{tabular}

Selain itu penggunaan varietas dan Tricoderma-Boron yang digunakan juga berpengaruh terhadap tinggi tanaman. Pemberian Trichoderma sp. pada tanaman telah diperlihatkan memberi respon yang positif pada pertumbuhan dan produksi tanaman (Herlina dan Pramesti, 2004). Selain itu, mekanisme sintesa protein, yang merupakan komponen senyawa kimia penting yang dibutuhkan tanaman dalam proses metabolismenya, dapat berlangsung dengan baik dengan pemberian Boron pada tanaman (Ali et al., 2015). Pemupukan Boron dengan konsentrasi tertentu juga diyakini berperan dalam membantu penyerapan dan transport fotosintat yang lebih baik (Mitra, 2015).

\section{Jumlah Cabang Produktif}

Data cabang produktif cabai besar dan sidik ragamnya pada umur 32 HST menunjukkan bahwa perlakuan varietas cabai besar berpengaruh sangat nyata sedangkan perlakuan kombinasi Trichoderma-Boron berpengaruh nyata. Namun interaksi antar kedua perlakuan berpengaruh tidak nyata. Ratarata jumlah cabang produktif berbagai varietas cabai besar pada perlakuan kombinasi Trichoderma-Boron 32 HST dapat dilihat pada Tabel 2.

Tabel 2. Jumlah cabang produktif berbagai varietas cabai besar pada kombinasi perlakuan Trichoderma-Boron pada 32 HST (cabang)

\begin{tabular}{|c|c|c|c|c|c|}
\hline \multirow{2}{*}{$\begin{array}{c}\text { Kombinasi } \\
\text { Trichoderma-Boron }\end{array}$} & \multicolumn{3}{|c|}{ Varietas } & \multirow{2}{*}{$\begin{array}{c}\text { Rata- } \\
\text { rata } \\
\text { (cabang) }\end{array}$} & \multirow{2}{*}{$\begin{array}{c}\text { NP BNT } \\
0.05\end{array}$} \\
\hline & Karina & Tombak & $\begin{array}{l}\text { Panex } \\
100 \mathrm{~F} 1\end{array}$ & & \\
\hline & \multicolumn{3}{|c|}{ 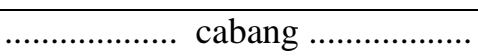 } & & \\
\hline Tanpa Trichoderma + tanpa Boron & 30.11 & 12.00 & 25.56 & $22.56 \mathrm{a}$ & \\
\hline T. harzianum $4 \mathrm{~g} \mathrm{tan}^{-1}$ & 21.22 & 7.44 & 22.44 & $17.04_{c}$ & \\
\hline T. asperellum $4 \mathrm{~g} \mathrm{tan}^{-1}$ & 22.56 & 4.33 & 27.67 & $18.19_{\mathrm{bc}}$ & 0.13 \\
\hline T. harzianum $4 \mathrm{~g} \mathrm{tan}^{-1}+$ Boron $1 \mathrm{~m} \mathrm{~L}^{-1}$ & 24.67 & 8.22 & 24.22 & $19.04_{b}$ & \\
\hline T. asperellum $4 \mathrm{~g} \mathrm{tan}^{-1}+$ Boron $1 \mathrm{mg} \mathrm{L}^{-1}$ & 28.22 & 8.11 & 24.56 & $20.30_{\mathrm{b}}$ & \\
\hline Boron $1 \mathrm{mg} \mathrm{L}^{-1}$ & 25.89 & 6.56 & 20.44 & $17.63_{\mathrm{c}}$ & \\
\hline Rata-rata & $25.44_{a}$ & $7.78_{\mathrm{b}}$ & $24.15_{\mathrm{a}}$ & & \\
\hline NP BNT 0.05 & & 0.15 & & & \\
\hline
\end{tabular}


Berdasarkan uji BNT pada taraf 0.05 pada Tabel 2 menunjukkan bahwa pada varietas Karina (V1) menghasilkan jumlah cabang produktif tertinggi pada 32 HST yaitu 25.44 cabang dan berbeda nyata dengan varietas Tombak (V2) dengan jumlah cabang produktif hanya 7.78 cabang. Jumlah cabang produktif varietas Karina dan Panex menunjukkan hasil yang tidak berbeda nyata. Jumlah cabang produktif yang tertinggi (22.56 cabang) ditunjukkan oleh perlakuan tanpa Boron dan Trichoderma (T0) yang berbeda nyata dengan perlakuan kombinasi lainnya. Namun, Trichoderma asperellum $4 \mathrm{~g} \mathrm{tan}^{-1}+$ Boron $1 \mathrm{mg}$ $\mathrm{L}^{-1}$ (T4) juga menghasilkan jumlah cabang produktif yang baik 20.30 cabang.

Trichoderma sp. diketahui dapat berperan sebagai Plant Growth Enhancer. Hal ini sesuai dengan pendapat Herlina dan Pramesti (2009) yang menyatakan bahwa Trichoderma sp. secara positif mempengaruhi perkembangan perakaran tanaman yang dapat mendukung pertumbuhan tanaman dan pada akhirnya memberi keuntungan pada hasil produksi tanaman. Selain itu, aplikasi pupuk Boron pada tanaman mampu memberikan unsur hara yang cukup bagi jumlah cabang tanaman cabai besar. Penambahan boron dengan konsentrasi rendah dapat meningkatkan laju dan keserempakan tumbuh tanaman karena boron merupakan unsur hara mikro yang dikaitkan dengan metabolisme hormon auksin (Julita et al., 2016).

\section{Jumlah Buah Gugur}

Hasil pengukuran dan sidik ragam jumlah buah gugur pada 58 HST menunjukkan perlakuan varietas cabai besar berpengaruh sangat nyata sedangkan perlakuan kombinasi Trichoderma-Boron dan interaksinya berpengaruh tidak nyata. Rata-rata jumlah buah gugur berbagai varietas cabai besar pada perlakuan kombinasi Trichoderma-Boron 58 HST dapat dilihat pada Tabel 3.

Berdasarkan uji BNT pada taraf 0.05 pada Tabel 3 menunjukkan bahwa pada varietas Tombak (V2) menghasilkan jumlah buah gugur per tanaman terendah pada 58 HST yaitu 0.69 buah dan berbeda nyata dengan varietas Panex 100 F1 (V3) dengan jumlah buah gugur per tanaman 5.11 buah. Beberapa faktor yang telah diduga mempengaruhi pengguguran bunga dan buah tanaman cabai diantaranya adalah kegagalan pembuahan, suhu yang tinggi (Thuy dan Kenji, 2015), dan kekurangan air terutama pada saat periode pembentukan bunga dan buah (Budiyati et al., 2017).

\section{Jumlah Buah per Tanaman}

Hasil pengukuran dan sidik ragam jumlah buah per tanaman pada umur 100 HST menunjukkan bahwa perlakuan varietas cabai besar berpengaruh sangat nyata sedangkan perlakuan kombinasi Trichoderma-Boron dan interaksinya berpengaruh tidak nyata. Rata-rata jumlah buah per tanaman berbagai varietas cabai besar pada perlakuan kombinasi Trichoderma-Boron umur 90 HST dapat dilihat pada Tabel 4. Berdasarkan uji BNT pada taraf 0.05 pada Tabel 4 menunjukkan bahwa pada varietas Karina (V1) menghasilkan jumlah buah per tanaman tertinggi pada 100 HST yaitu 24.67 buah dan berbeda nyata dengan varietas Tombak (V2) dan varietas Panex 100 F1 (V3) dengan jumlah buah per tanaman masingmasing 10.22 buah dan 5.91 buah.

Tabel 3. Jumlah buah gugur berbagai varietas cabai besar pada kombinasi perlakuan TrichodermaBoron pada 58 HST

\begin{tabular}{|c|c|c|c|c|}
\hline \multirow{2}{*}{ Kombinasi Trichoderma-Boron } & \multicolumn{3}{|c|}{ Varietas } & \multirow{2}{*}{ Rata-rat: } \\
\hline & Karina & Tombak & Panex $100 \mathrm{~F} 1$ & \\
\hline Tanpa Trichoderma + tanpa Boron & 5.33 & 1.22 & 3.89 & 3.48 \\
\hline T. harzianum $4 \mathrm{~g} \mathrm{tan}^{-1}$ & 4.11 & 0.89 & 5.11 & 3.37 \\
\hline T. asperellum $4 \mathrm{~g} \mathrm{tan}^{-1}$ & 3.67 & 0.22 & 5.33 & 3.07 \\
\hline T. harzianum $4 \mathrm{~g} \mathrm{tan}^{-1}+$ Boron $1 \mathrm{mg} \mathrm{L}^{-1}$ & 4.89 & 0.33 & 5.89 & 3.70 \\
\hline T. asperellum $4 \mathrm{~g} \mathrm{tan}^{-1}+$ Boron $1 \mathrm{mg} \mathrm{L}^{-1}$ & 7.22 & 1.11 & 5.67 & 4.67 \\
\hline Boron $1 \mathrm{mg} \mathrm{L}^{-1}$ & 5.00 & 0.33 & 4.78 & 3.37 \\
\hline Rata-rata & $5.04 \mathrm{a}$ & $0.69_{\mathrm{a}}$ & $5.11_{b}$ & \\
\hline
\end{tabular}

Keterangan: Angka-angka yang diikuti oleh huruf yang berbeda pada kolom yang sama adalah berbeda nyata pada uji DMRT 0.05. NP = nilai pembanding. 
Tabel 4. Rata-rata jumlah buah per tanaman berbagai varietas cabai besar pada kombinasi perlakuan Trichoderma-Boron pada 100 HST (buah)

\begin{tabular}{|c|c|c|c|c|}
\hline \multirow{2}{*}{$\begin{array}{c}\text { Kombinasi } \\
\text { Trichoderma-Boron }\end{array}$} & \multicolumn{3}{|c|}{ Varietas } & \multirow{2}{*}{$\begin{array}{c}\text { Rata-rata } \\
\text { (buah) }\end{array}$} \\
\hline & Karina & Tombak & Panex $100 \mathrm{~F} 1$ & \\
\hline & \multicolumn{3}{|c|}{. Buah ....................... } & \\
\hline Tanpa Trichoderma + tanpa Boron & 32.11 & 9.67 & 5.67 & 15.81 \\
\hline T. harzianum $4 \mathrm{~g} \mathrm{tan}^{-1}$ & 25.56 & 13.00 & 4.11 & 14.22 \\
\hline T. asperellum $4 \mathrm{~g} \mathrm{tan}^{-1}$ & 23.89 & 7.33 & 6.67 & 12.63 \\
\hline T. harzianum $4 \mathrm{~g} \mathrm{tan}^{-1}+$ Boron $1 \mathrm{mg} \mathrm{L}^{-1}$ & 22.78 & 13.00 & 8.56 & 14.78 \\
\hline T. asperellum $4 \mathrm{~g} \mathrm{tan}^{-1}+$ Boron $1 \mathrm{mg} \mathrm{L}^{-1}$ & 26.33 & 10.78 & 5.44 & 14.19 \\
\hline Boron $1 \mathrm{mg} \mathrm{L}^{-1}$ & 17.33 & 7.56 & 5.00 & 9.96 \\
\hline Rata-rata & $24.67 \mathrm{a}_{\mathrm{a}}$ & $10.22 b_{b}$ & $5.91 c_{c}$ & \\
\hline NP BNT 0.05 & & 0.19 & & \\
\hline
\end{tabular}

Keterangan: Angka-angka yang diikuti huruf tidak sama pada baris $(a, b, c)$ berarti berbeda nyata pada taraf uji lanjut $\mathrm{BNT} 0.05$. NP = nilai pembanding.

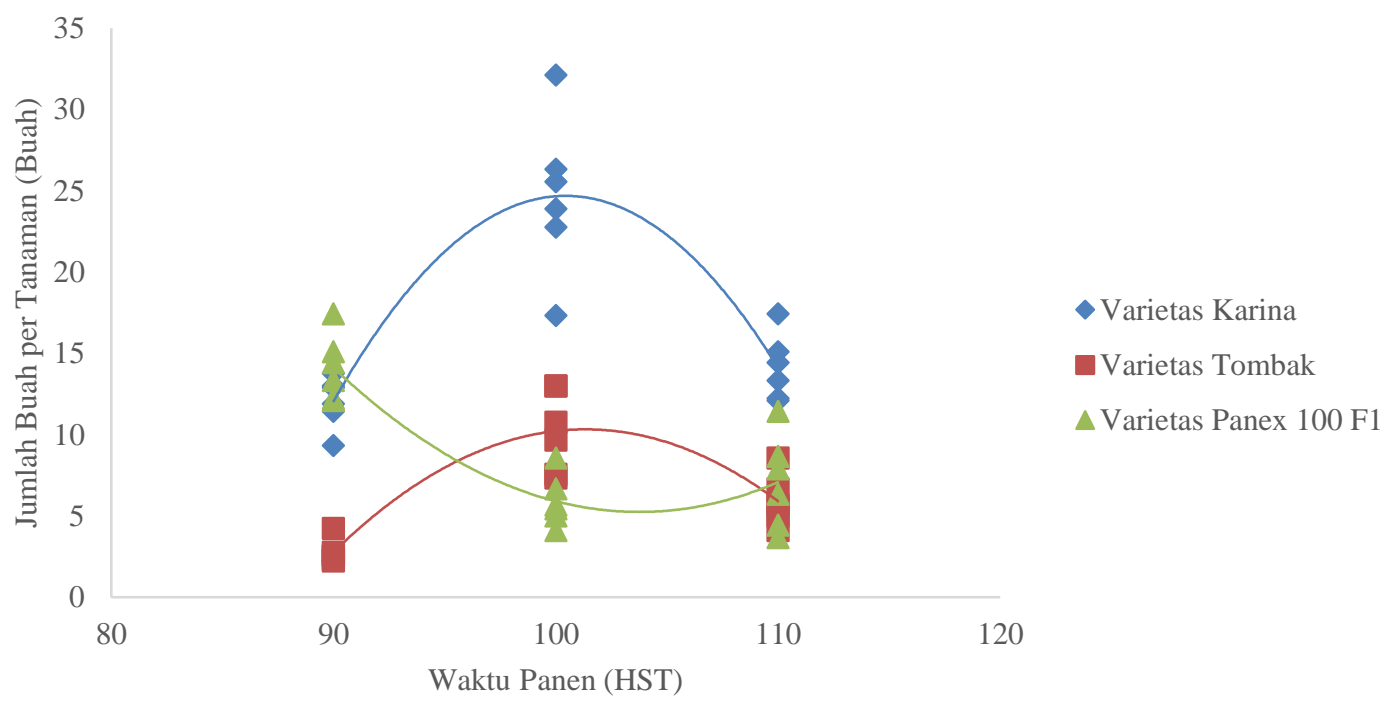

Gambar 1. Jumlah buah per tanaman cabai besar pada 90 HST, 100 HST dan 110 HST.

Gambar 1 menunjukkan bahwa rata-rata jumlah buah per tanaman pada varietas Karina, dan varietas Tombak mengalami peningkatan jumlah produksi dari 90 HST sampai 100 HST. Namun, kedua varietas mengalami penurunan produksi dari 100 HST sampai 110 HST. Sebaliknya, jumlah buah yang dipanen pada varietas Panex 100 F1 mengalami penurunan pada 90 HST sampai 100 HST yang selanjutnya menunjukkan peningkatan jumlah buah per tanaman pada 110 HST. Secara umum perlakuan pemberian Trichoderma dan pemupukan Boron berpengaruh tidak nyata terhadap jumlah buah per tanaman.

Produksi cabai besar dipengaruhi oleh varietas. Rendahnya jumlah buah per tanaman yang dihasilkan oleh varietas Panex 100 F1 ini terkait dengan jumlah buah gugur yang tinggi, sedangkan varietas Karina memiliki jumlah buah per tanaman yang lebih tinggi terkait dengan jumlah buah gugurnya yang lebih sedikit. Selaint faktor lingkungan, pertumbuhan dan produksi tanaman juga dipengaruhi oleh potensi genetik dari suatu varietas (Asnijar, 2013). Beberapa parameter pertumbuhan dan produksi tanaman cabai diketahui lebih banyak ditentukan oleh faktor genetik dibanding oleh lingkungan (Syukur et al., 2010).

Keberhasilan dalam mencapai produksi yang tinggi akan ditentukan oleh penggunaan varietas unggul yang merupakan salah stu komponen teknologi yang penting. Varietas unggul dikenal tahan terhadap hama penyakit, daya adaptasi yang baik dan memiliki tingkat 
produksi tinggi dibanding varietas lokal. Kelebihan ini mendorong respons yang lebih baik terhadap pemupukan yang diberikan sehingga produksi yang diperoleh dapat meningkat. Selain itu Trichoderma berpengaruh terhadap produksi, hal ini sesuai dengan pendapat Harman (2000) bahwa ketahanan tanaman terhadap berbagai penyakit dapat diinduksi melalui sistem interaksi Trichoderma sp. dan tanaman disamping manfaat jamur ini yang dapat bersifat antagonis terhadap patogen tular tanah.

\section{Panjang Buah Per Tanaman}

Hasil pengukuran dan sidik ragam panjang buah per tanaman pada umur 110 HST menunjukkan bahwa perlakuan varietas cabai besar dan interaksinya tidak berpengaruh nyata sedangkan perlakuan kombinasi TrichodermaBoron berpengaruh nyata. Rata-rata panjang buah per tanaman berbagai varietas cabai besar pada perlakuan kombinasi Trichoderma-Boron umur 110 HST dapat dilihat pada Tabel 5.

Berdasarkan uji BNT pada taraf 0.05 pada Tabel 5 menunjukkan bahwa perlakuan Trichoderma asperellum $4 \mathrm{~g} \mathrm{tan}^{-1}+$ Boron $1 \mathrm{mg}$ $\mathrm{L}^{-1}$ (T4) menghasilkan panjang buah per tanaman tertinggi yaitu $9.93 \mathrm{~cm}$ dan berbeda nyata dengan perlakuan Trichoderma harzianum $4 \mathrm{~g} \mathrm{tan}^{-1}+$ Boron $1 \mathrm{mg} \mathrm{L}^{-1}$ (T3) menunjukkan panjang buah per tanaman terendah yaitu $8.09 \mathrm{~cm}$.

Herlina dan Pramesti (2010) menyatakan bahwa Trichoderma sp. merupakan salah satu mikroba fungsional yang dapat berperan antara lain sebagai pupuk biologis tanah, organisme pengurai bahan organik dalam tanah, dan agen hayati dan stimulator pertumbuhan tanaman. Suwahyono dan Wahyudi (2004) menunjukkan adanya peningkatan jumlah akar dan lebar daun, serta regenerasi pucuk daun tanaman Alpukat yang sebelum terserang penyakit dengan pemberian Trichoderma sp.

Penggunaan pupuk Boron terbukti dapat meningkatkan pertumbuhan dan perkembangan buah cabai (Harris et al., 2018). Penelitian Rafique et al. (2012) yang menemukan adanya peningkatan hasil dari buah cabai keriting yang berkisar antara 11-19\% dengan aplikasi Boron. Aplikasi pupuk Boron sebanyak 1-2 kg B hapada tanaman cabai juga ditemukan dapat meningkatkan diameter buah dan berat segar buah (Shil et al., 2013). Selain itu, pupuk Boron diketahui berperan dalam menjaga integritas dinding sel buah dan terbukti meningkatkan kualitas fisik buah manggis saat diaplikasikan bersama-sama dengan pupuk yang mengandung unsur Kalsium pada stadia awal perkembangan buah (Kurniawan et al., 2016).

Tabel 5. Panjang buah per tanaman berbagai varietas cabai besar pada kombinasi perlakuan Trichoderma-Boron pada 110 HST $(\mathrm{cm})$

\begin{tabular}{|c|c|c|c|c|c|}
\hline \multirow{2}{*}{$\begin{array}{c}\text { Kombinasi } \\
\text { Trichoderma-Boron }\end{array}$} & \multicolumn{3}{|c|}{ Varietas } & \multirow[b]{2}{*}{$\begin{array}{l}\text { Rata-rata } \\
\quad(\mathrm{cm})\end{array}$} & \multirow{2}{*}{$\begin{array}{l}\text { NP BNT } \\
0.05\end{array}$} \\
\hline & Karina & Tombak & $\begin{array}{l}\text { Panex } \\
100 \mathrm{~F} 1\end{array}$ & & \\
\hline & & $\ldots \mathrm{cm}$ & & & \\
\hline Tanpa Trichoderma + tanpa Boron & 9.09 & 9.45 & 8.58 & $9.04_{\mathrm{ab}}$ & \\
\hline T. harzianum $4 \mathrm{~g} \mathrm{tan}^{-1}$ & 9.61 & 8.91 & 6.14 & $8.22 \mathrm{~b}$ & \\
\hline T. asperellum $4 \mathrm{~g} \mathrm{tan}^{-1}$ & 9.67 & 10.65 & 9.20 & $9.84 \mathrm{a}$ & 0.08 \\
\hline T. harzianum $4 \mathrm{~g} \mathrm{tan}^{-1}+$ Boron $1 \mathrm{mg} \mathrm{L}^{-1}$ & 9.73 & 8.60 & 5.94 & $8.09_{\mathrm{c}}$ & \\
\hline T. asperellum $4 \mathrm{~g} \mathrm{tan}^{-1}+$ Boron $1 \mathrm{mg} \mathrm{L}^{-1}$ & 10.36 & 10.34 & 9.08 & $9.93_{\mathrm{a}}$ & \\
\hline Boron $1 \mathrm{mg} \mathrm{L}^{-1}$ & 9.62 & 11.12 & 8.08 & $9.60_{a}$ & \\
\hline Rata-rata & 9.68 & 9.84 & 7.84 & & \\
\hline
\end{tabular}

Keterangan: Angka-angka yang diikuti huruf tidak sama pada kolom (a, b, c) berarti berbeda nyata pada taraf uji lanjut BNT 0.05. NP = nilai pembanding. 


\section{UCAPAN TERIMAKASIH}

Peneliti mengucapkan terimakasih kepada LP2M UNHAS yang telah mendanai penelitian ini melalui program BOPTN UNHAS 2017.

\section{KESIMPULAN}

Berdasarkan hasil penelitian yang telah dilakukan, maka dapat disimpulkan bahwa interaksi yang memberikan hasil terbaik antar kedua perlakuan yaitu pada perlakuan Trichoderma asperellum $4 \mathrm{~g} \mathrm{tan}^{-1}$, dan varietas Panex 100 F1 pada tinggi tanaman yaitu 47.77 $\mathrm{cm}$. Perlakuan Varietas Karina secara nyata memberikan hasil terbaik dengan jumlah cabang produktif tertinggi pada 32 HST yaitu 5.31 cabang, jumlah buah per tanaman tertinggi pada 100 HST yaitu 5.20 buah. Perlakuan Trichoderma-Boron secara nyata menunjukkan panjang buah per tanaman tertinggi pada 110 HST adalah Trichoderma asperellum $4 \mathrm{~g} \mathrm{tan}^{-1}$ + Boron $1 \mathrm{mg} \mathrm{L}^{-1}$ yaitu $3.23 \mathrm{~cm}$.

\section{DAFTAR PUSTAKA}

Ali, F., A. Ali, H. Gul, M. Sharif, A. Sadiq, A. Ahmed, A. Ullah, A. Mahar, S.A. Kalhoro. 2015. Effect of boron soil application on nutrients efficiency in tobacco leaf. American. J. of Plant Sci. 6: 1391-1400.

Alqamari. 2016. Pertumbuhan dan hasil 3 varietas cabai merah (Capsicum annuиm L.) dengan aplikasi kalium sulfat. J. Pertanian Tropik. 3(28): 249-255.

Asnijar. 2013. Pengaruh varietas dan konsentrasi pupuk bayfolan terhadap pertumbuhan dan hasil tanaman cabai (Capsicum annum L.). Jurnal Agrista. 17(2): 60-66.

[BPS] Badan Pusat Statistik. 2013. http://www.bps.go.id/hasil_publikasi/ SI_2013/index3.php?pub=Statistik+ Indonesia+2013 [7 September 2016].
Budiyati, I., R. Suwignyo, H. Renih, S. Susilawati. 2017. Response of red chilli varieties under drought stress. Russian Journal of Agricultural and SocioEconomic Sciences. 66: 361-368.

[Deptan] Departemen Pertanian. 2009. Konsumsi Perkapita Sayuran di Indonesia Periode 2003-2006. http:// www.deptan.go.id [30 Mei 2009].

Harman, G.E. 2000. Myth and dogmas of biocontrol changes in perceptions derived from research on Trichoderma harzinum T-22. Plant Disease. 84(4): 377-393.

Harris, K.D., T. Vanajah, S. Puvanitha. 2018. Effect of foliar application of Boron and Magnesium on growth and yield of green chilli (Capsicum annum L.). AGRIEAST: Journal of Agricultural Sciences. 12(1): 26-33.

Hayati, E., T. Mahmud, R. Fazil. 2012. Pengaruh jenis pupuk organik dan varietas terhadap pertumbuhan dan hasil tanaman cabai (Capsicum annum L.). J. Floratek. 7: 173-181.

Herlina, L., D. Pramesti. 2004. Penggunaan kompos aktif Trichoderma harzianum dalam meningkatkan pertumbuhan tanaman cabai. Jurnal Fakultas Matematika dan Ilmu Pengetahuan Alam Universitas Negeri Semarang: 11-17.

Julita, H.D., Syamsuddin, R. Hayati. 2016. Pengaruh pemberian nitrogen dan boron melalui daun terhadap mutu benih kedelai (Glycine $\max (L$.$) Merril). J.$ Floratek. 11(1): 10-17.

Kumar, M., A.K. Jha, S. Hazarika, B.C. Verma, B. U. Choudhury, T. Ramesh, P. Moirangthem, R. Kumar, Brajendra, D. J. Rajkhowa, A. Kumar, M. H. Dev. 2016. Micronutrients (B, Mo, Zn) for improving crop production on acidic soils of Northeast India. Natl. Acad. Sci. Lett. 39(2): 85-89. 
Kurniawan, V., R. Poerwanto, D. Efendi. 2016. Waktu dan dosis aplikasi kalsium dan boron untuk pengendalian getah kuning pada buah manggis (Garcinia mangostana L.) di tiga sentra produksi. J. Hort. Indonesia. 7(1): 21-30.

Marschner, P. 2012. Marschner's Mineral Nutrition of Higher Plants (3 ed.). UK: Elsevier.

Mitra, G.N. 2015. Regulation of Nutrient Uptake by Plants : A Biochemical and Molecular Approach. India: Springer.

Prayudi, B. 2010. Budidaya dan Pasca Panen Cabai Merah (Capsicum annum L.). Badan Penelitian dan Pengembangan Pertanian, Balai Pengkajian Teknologi Pertanian, Jawa Tengah.

Poulton, J.L., R.T. Koide, A.G. Stephenson. 2011. Effects of Trichoderma infection and soil phosphorus availability on invitro and in-vivo pollen performance in Lycopersicon esculentum (Solanaceae). American J. Botany. 88: 1786-1793.

Rafique, E., M. Mahmood-ul-Hassan, K.M. Khokhar, M. Ishaq, M. Yousra, T. Tabassam. 2012. Boron requirement of chili (Capsicum annuum L.): Proposed diagnostic criteria. J. Plant Nutr. 35: 739-749.

Rosmana, A., N. Nasaruddin, H. Hendarto, A. A. Hakkar, N. Agriansyah. 2016. Endophytic Association of Trichoderma asperellum within Theobroma cacao Suppresses Vascular Streak Dieback Incidence and Promotes Side Graft Growth. Mycobiology. 44(3): 180-186.
Shil, N.C., H.M. Naser, S. Brahma, M.N. Yousuf, M.H. Rashid. 2013. Response of chilli (Capsium annuum L.) to Zinc and Boron application. Bangladesh J. Agril. Res. 38(1): 49-59.

Subhan, N. Sutrisno, R. Sutarya. 2012. Pengaruh cendawan Trichoderma sp. terhadap tanaman tomat pada tanah andisol. Berita Biologi. 11(3): 389-400.

Sumarni, N., A. Muharam. 2003. Budidaya Cabai Merah. Balai Penelitian Tanaman Sayuran. Lembang.

Sutedjo, M.M. 2010. Pupuk dan Cara Pemupukan. PT. Rieneka Cipta. Jakarta.

Suwahyono, U., P. Wahyudi. 2004. Penggunaan Biofungisida pada Usaha Perkebunan. http://www.iptek.net.id/ ind/terapan/terapan [26 April 2013].

Syukur, M., S. Sujiprihati, J. Koswara, Widodo. 2007. Pewarisan ketahanan cabai (Capsicum annuum L.) terhadap antraknosa yang disebabkan oleh Colletotrichum acutatum. Bul. Agron. 35: 112-117.

Syukur, M., S. Sujiprihati, R. Yunianti, K. Nida. 2010. Pendugaan komponen ragam, heritabilitas dan korelasi untuk menentukan kriteria seleksi cabai (Capsicum annuum L.) populasi F5. J. Hort. Indonesia. 1(2): 74-80.

Thuy, T.L., M. Kenji. 2015. Effect of high temperature on fruit productivity and seed-set of sweet pepper (Capsicum annиuт L.) in the field condition. J. of Agri. Sci. and Tech. 5(12): 515-520. 